ОСОБЛИВОСТІ ЄВРОПЕЙСЬКИХ МОДЕЛЕЙ ДЕРЖАВНОЇ ПОЛІТИКИ У РОЗВИТКУ ТВАРИННИЦТВА

\title{
FEATURES OF EUROPEAN MODELS OF STATE POLICY IN THE DEVELOPMENT OF ANIMAL HUSBANDRY
}

\begin{abstract}
У статті акцентується на значенні галузі тваринництва, основним призначенням якої $\epsilon$ забезпечення виробництва високопоживних харчових продуктів тваринного походження в обсягах, котрі відповідають нормам продовольчої безпеки європейських країн. Схарактеризовано основні підгалузі тваринництва й наведено кількісні та якісні показники їхнього розвитку. Виявлено спільні риси в розвитку тваринництва в різних країнах $і$ виокремлено його особливості. Виявлено, що одним з основних чинників забезпечення інтенсивного розвитку тваринництва $є$ досягнення оптимального співвідношення галузей, виробничої спеціалізації та концентрації поголів'я тварин. Ці актуальні питання належать до пріоритетних у завданнях аграрної політики європейських країн. Указано, що важливим процесом у формуванні й здійсненні державної політики кожної європейської країни є визначення сутності проблем, притаманних галузі тваринництва, котрі потребують державного втручання. Викладене означає, що державна політика в основному орієнтована на отримання конкретного результату в процесі розв'язання важливих питань. Встановлено, що політика кожної європейської держави реалізується в багатовимірному соціально-політичному просторі й базується на законодавчій, організаційній і срінансово-економічній діяльності, котрі забезпечують створення відповідних умов і стимулів для стабільного розвитку тваринництва. Запропоновано під час розроблення та реалізації заходів державної політики в європейських країнах передбачити забезпечення інноваційних виробничих процесів, котрі сприяють стабілізації досягнутих позицій у розвитку тваринництва шляхом посиленого нарощування та розширеного відтворення високопродуктивного поголів'я худоби й птиці, застосування прогресивних технологій утримання худоби й птиці, зміцнення кормової бази шляхом розширення площ культурних пасовищ, збільшення обсягів якісної тваринницької продукції та встановлення на неї оптимальних цін.

Ключові слова: європейські краӥни, державна політика, тваринництво, особли-
\end{abstract}

вості, моделі, продукція тваринництва, харчові продукти.

The article focuses on the importance of the livestock industry, the main purpose of which is to ensure the production of highly nutritious food products of animal origin in volumes that meet the food safety standards of European countries. The main sub-sectors of animal husbandry are characterized and quantitative and qualitative indicators of their development are given. Common features in the development of animal husbandry in different countries are identified and its features are highlighted. It is revealed that one of the main factors for ensuring the intensive development of animal husbandry is the achievement of an optimal ratio of industries, production specialization and concentration of livestock. These topical issues are among the priorities in the tasks of agricultural policy of European countries. It is indicated that an important process in the formation and implementation of the state policy of each European country is to determine the essence of problems inherent in the livestock industry that require state intervention. The above means that public policy is mainly focused on obtaining a specific result in the process of solving important issues. It is established that the policy of each European state is implemented in a multidimensional socio-political space and is based on legislative, organizational, financial and economic activities that ensure the creation of appropriate conditions and incentives for the stable development of animal husbandry. It is proposed to provide for the development and implementation of state policy measures in European countries to provide for the provision of innovative production processes that contribute to the stabilization of achieved positions in the development of animal husbandry due to the increased build-up and expanded reproduction of high-performance livestock and poultry, the use of advanced technologies for keeping livestock and poultry, strengthening the feed base by expanding the area of cultivated pastures, increasing the volume of high-quality livestock products and setting optimal prices for them. Key words: European countries, state policy, animal husbandry, features, models, livestock products, food products.
Постановка проблеми в загальному вигляді. Тваринництво відіграє важливу роль у підвищенні життєвого рівня населення (продукти тваринницького походження мають високу енергетичну й поживну цінність) і розв'язанні соціально-економічних проблем фермерських господарств європейських країн. Нині держави європейських країн, взаємодіючи з багатьма суб'єктами господарювання, розробляють досконалу державну політику з метою спрямування ії на ефективне розв'язання утворюваних суспільних проблем, особливо тих із них, котрі стосуються галузі тваринництва й піддаються безпосередньому впливу приватних структур і громадян, що переслідують свої цілі й особисті інтереси стосовно виробництва конкурентоздатної тваринницької продукції.

Європейський досвід виробництва м'ясної та молочної продукції свідчить, що в основі ефективного ведення тваринництва $€$ вдале поєднання цілого комплексу заходів державної політики: регіональний підхід до розвитку цієї галузі, оптимальне збалансування 
на ринку ціни й собівартості виробництва тваринницької продукції, пріоритетний розвиток спеціалізованих підгалузей, використання збалансованих високопоживних кормів і мікроелементів, випасання великої рогатої худоби на продуктивних пасовищах, високий рівень селекційно-племінної роботи.

Аналіз останніх досліджень і публікацій. Теоретико-методологічні аспекти проведеного дослідження базуються на узагальненні наукових розробок по вивченню державної політики й механізмів державного управління, котрі надавалася такими зарубіжними науковцями, як Дж. Алмонд, Дж. Андерсон, П. Браун, Е. Вайнінґ, Д. Веймер, К. Вайс, М. Говлет, В. Дан, Д. Істон, Л. Пал, В. Парсонс, М. Рамеш та іншими.

Ця проблематика вивчалася в працях таких відомих вітчизняних науковців, як В. Андріяш, В. Бакуменко, О. Валевський, О. Кілієвич, Ю. Ковбасюк, М. Латинін, В. Мамонова, В. Ребкало, Є. Романенко, В. Тертичка й багатьох інших учених. Ґрунтовне дослідження аспектів аграрної політики в Україні і європейських країнах, формування механізму державного регулювання стану розвитку галузі тваринництва й підвищення його ефективності проводилося в наукових працях вітчизняних вчених: В. Андрійчука, П. Березівського, В. Бовсуновського, В. Геєця, М. Маліка, М. Місюка, П. Пуцентейла, П. Саблука, I. Свиноуса й інших.

Виділення не вирішених раніше частин загальної проблеми. Однак досить багато проблем, що стосуються визначення сутності, особливостей, принципів розробки й здійснення моделей державної політики в європейських країнах залишаються не досить дослідженими.

Формулювання цілей статті. Мета статті полягає в обґрунтуванні особливостей зарубіжного досвіду в частині формування державної політики та її реалізації в розвитку галузі тваринництва.

Виклад основного матеріалу. Дослідження показали, що тваринництво $€$ однією з важливих галузей сільського господарства європейських країн, що безпосередньо впливає на його економіку й рівень забезпечення населення необхідними й калорійними харчовими продуктами. Власне цим важливим процесам спроможна посприяти державна політика, можливості якої досить великі, а тому її здійснення в галузі тваринництва не тільки забезпечує йому ефективний розвиток, але й покращення взаємовідносин між суб'єктами господарювання, розвиток інтеграційних процесів, посилення продо- вольчої безпеки, економічної та соціальної стабільності в кожній європейській країні.

у такому випадку сформована державна політика насамперед спрямовується на досягнення стратегічних рубежів розвитку кожної країни й на максимальне задоволення потреб та інтересів населення сільських територій, особливо працівників тваринництва. Мало того, виконання цих важливих функцій державної політики в наявних умовах розвитку більшості європейських країн зумовлюється необхідністю своєчасного реагування керівництва держав та їхніх інституцій. А тому більшість урядів європейських країн спрямовує свою активну діяльність на реалізацію державної політики, покращення та вдосконалення структурного наповнення раніше чинних державних програм, ураховуючи сучасні надбання в розвитку галузі тваринництва.

Натепер політика країн Європейського Союзу(далі - ЄС) Є важливим самостійним складником, оскільки являє собою сукупність форм і методів упорядкованої діяльності держав ЄС та їхніх інститутів, що спрямовуються на формування раціонального й сталого розвитку сільського господарства та його галузей на територіях у межах європейської спільноти.

Встановлено, що умови господарювання в європейських країнах залежать від реалізації сучасних концепцій (в основі знаходяться зміст і форми діяльності держави) державної політики, що визначає динамічні тенденції їхного розвитку. Державна політика відіграє важливу роль у соціально-політичній системі суспільства, оскільки забезпечує динамічну єдність і взаємодію основних сфер суспільного життя в кожній країні. Необхідність дослідження функцій, моделей та особливостей державної політики зумовлюється активною соціально-політичною позицією європейських країн і появою тут нових соціально-політичних структур і інституцій.

Відзначимо, що в політичному житті суспільства західних європейських країн у виробленні державних рішень із найбільш важливих економічних і соціальних питань беруть участь численні організації з різним ступенем активності й впливу на політичні процеси. Слід зауважити, що державна політика європейських країн завжди має соціальне підґрунтя та спрямованість і вважається динамічною, послідовною та ефективною. У контексті зазначеного важливо державну політику (враховуючи їі характеристики в окремо взятих європейських країнах) розглядати як:

- соціальний механізм, основними складовими частинами якого є послідовність визначення суспільних цілей, обґрунтування та 
прийняття державно-управлінських рішень, формування ресурсів для реалізації суспільних цілей;

- соціальну діяльність, метою якої є створення необхідних умов для забезпечення соціального партнерства (залучення до управління суспільними інституціями різних соціальних груп і громадських об'єднань) між державною владою та суб'єктами громадянського суспільства;

- інституціональний процес погодженості між державною владою та суспільством із метою забезпечення стабільного й ефективного суспільного розвитку.

Отже, функції державної політики європейських країн спрямовуються на розвиток суспільства, узгодження та реалізацію різних соціальних інтересів, організацію та управління здійсненням суспільних і виробничих процесів, встановлення оптимальних форм політико-державної діяльності.

Слід зазначити, що в країнах ЄС сформовані майже всі типи проблемних територій аграрної інтеграції, котрі потребують конкретної сфери діяльності політики, що займає різні ключові позиції в соціально-економічному розвитку цих країн. Тут варто зауважити, що не всі країни мають однакові економічні й соціальні можливості, котрі роблять їх привабливими для здійснення господарської діяльності. У такому випадку вкрай важливим є вивчення питання, чому й з яким результатом уряди проводять спеціальні курси дій або бездіяльності, що дає можливість отримати інформацію про напрями політики й основні умови, котрі визначають її вибір у різних країнах [4]. А тому європейська політика спрямовується на економічне зближення розвинутих країн із метою допомоги менш розвиненим, покращення їхньої конкурентоспроможності, забезпечення співпраці країн та їхніх регіонів для посилення економічного значення національних кордонів.

Дослідження показали, що державна політика позитивно вплинула на відроджувальні процеси у тваринництві й сприяла виявленню відмінних рис економічного й соціального розвитку Нідерландів. Відродженню західноєвропейського сільського господарства сприяла Спільна аграрна політика (далі - САП), в основу якої було покладено основні завдання: добитися високої продуктивності сільськогосподарського виробництва шляхом його модернізації та техніко-технологічного забезпечення; раціонально й ефективно використовувати виробничі, зокрема генетичні, й трудові ресурси; підвищити рівень життя сільського населення шляхом збільшення його доходів; сприяти створенню достатньої кількості про- довольчих продуктів тваринного походження та стабілізувати ринкову інфраструктуру; забезпечити процес реалізації споживачам тваринницької продукції за чітко сформованими й доступними цінами.

Європейський Союз також надає підтримку своїм фермерам у рамках Спільної аграрної політики. Умежахцієїпрограмивстановлюється високий рівень внутрішньої ціни на конкретний продукт і паралельно (з метою вирівнювання ціни) ідентичний імпортний товар обкладається високим митом. Натомість надходження від зняття мита на імпортні товари формують фонд для фінансування експортних субсидій.

Серед субсидій, що можуть отримувати фермери в Нідерландах, існує програма гарантування частини позики, котру готова взяти на себе держава. Претендентами на цю програму виступають малі й середні підприємці, зокрема молоді фермери віком до 39 років. Водночас додаткові кошти позики, котрі фермер отримує під гарантії, мають бути витрачені на чітко визначені цілі (оптимізацію виробництва, підтримання цін, покращення якості продукції, умов утримання тварин). Підтримувані ціни сприяють виробництву надлишкових обсягів різних видів сільськогосподарської продукції, зокрема тваринницької, котрі ЄС експортує за низькими субсидованими цінами. Відповідно, основними цілями Спільної аграрної політики ЄС визначено стабільність продовольчого ринку, виробництво якісної сільськогосподарської продукції, особливо тваринницької, захист ї̈ від конкурентів, забезпечення населення високопоживними продуктами за прийнятними цінами, організацію доходів виробників [3].

У країнах Європейського Союзу державна політика спрямовується на забезпечення функціонування системи управління виробництвом продукції за такими моделями:

- державна (характерна для Данії, Естонії, Фінляндії, Литви й Нідерландів), де акредитація та сертифікація продукції здійснюються державними інституціями, а держава виступає як сертифікаційний орган влади, а тому свої контрольні функції делегує контрольним органам (державним установам);

- приватна (функціонує в Австрії, Бельгії, Болгарії, на Кіпрі, у Франції, Німеччині, Греції, Угорщині, Ірландії, Італії, Латвії, Португалії, Румунії, Словенії, Швеції та Великобританії) є найпоширенішою системою, в межах якої держава акредитує приватні контрольні органи й здійснює нагляд за ними. У більшості випадків уповноважений орган влади делегує завдання здійснення контролю одному або кільком контрольним органам (приватним); 
- державно-приватна (притаманна Чеській Республіці, Люксембургу, Мальті, Польщі, Словаччині, Іспанії) є найпоширенішою, інспектування та сертифікація тут проводиться приватними контрольними органами. Держава лише акредитує офіційний наглядовий орган для проведення планових і вибіркових інспекцій (виробників, переробників, трейдерів).

Між тим, натепер у європейських країнах створено потужну політико-правову базу, котра регулює діяльність державних органів, зокрема в конституціях знаходять чітке відбиття норми й способи, що визначають процес створення цих органів, ухвалення ними рішень і розподіл компетенції та повноважень. Окрім цього, особливості діяльності державних органів країн ЄC із різними формами державного устрою базуються на багатих державницьких традиціях європейського суспільства. У цьому контексті особливо успішними $є$ нові члени $€ C$, котрі за більшістю порівнянь не в змозі зрівнятися з уже давно дійовими членами ЄС (Скандинавія, Німеччина, Франція), однак за порівняно короткий час свого існування майже наблизилися до Італії, Греції.

Основна особливість скандинавської (Данія, Норвегія, Фінляндія, Швеція) специфічної моделі політики полягає в тому, що вона в основному спрямована на задоволення потреб суспільства й забезпечує реалізацію основної мети держави, що втілюється в її економічному розвитку, зокрема на забезпечення високої частки внутрішнього валового продукту, нагромадження в державі фінансових ресурсів, налагодження формування державної політики доходів, дотримання рівності й справедливості в процесі їхнього розподілу, соціальний захист населення.

Важливою особливістю запровадження державної політики у Швеції є те, що в її основу покладено інтеграційний напрям самостійного розвитку регіонів (ураховуються стійкі переваги й власний економічний потенціал). Наразі держава бере участь у фінансуванні інвестиційних та інноваційних проєктів із метою підвищення конкурентоспроможності регіонів на внутрішньому й зовнішньому ринках. Попри це основні інструменти політики забезпечують вирівнювання доходів і витрат регіонів і надання їм дотацій для ефективного розвитку тваринництва.

Здебільшого в Ірландії, Греції, Португалії, Іспанії є досить багато бідних регіонів, в яких державна політика здійснюється в умовах низького рівня розвитку тваринництва й національної економіки в порівнянні з іншими країнами-членами ЄC. Водночас у Великобританії державна політика спрямовується на перероз- поділ надлишкових і мобільних капіталів із регіонів прискореного розвитку (донорів) у депресивні (реципієнти) 3 метою стимулювання економічного розвитку депресивних регіонів і подолання міжними дисбалансу. Затакої умови ряд прийнятих законодавчих актів (прийняття бюджету та інших фінансових біллів) уможливлюють розширення стимулів (пільгових субсидій, вільної амортизаційної політики, фінансової підтримки) для проблемних регіонів.

Суттєва увага вирівнюванню рівнів економічного розвитку регіонів надається і в державній політиці Канади. Цей процес здійснюється за допомогою прямих фінансових трансфертів у границях надання допомоги слабо розвиненим регіонам і реалізації цільових державних програм, у котрих передбачається забезпечити розвиток і вдосконалення всіх видів інфраструктур, стимулювання приватних інвестицій, надання податкових пільг, субсидій і підтримки розвитку тваринництва в бізнесових структурах.

Встановлено, що для кожної європейської країни характерні свої особливості формування та здійснення моделей державної політики, котрі знаходять своє відбиття в національних традиціях, менталітеті, фінансових можливостях і соціально-економічному розвитку країни. Водночас особливістю кожної державної політики є те, що вона знаходиться в жорсткій залежності від політичних та юридичних процедур, котрі в кожній країні мають свої відмінності в їі формуванні й здійсненні. Кожна з моделей зорієнтована на задоволення суспільних потреб своїх громадян, забезпечує їм високий рівень та якість життя, сприяє відокремленню функцій соціального захисту від функцій ринкового господарювання.

Заслуговує на увагу, що державна політика більшості країн Європейського союзу вивела галузь тваринництва на високі рубежі ефективного розвитку. Тут суттєва увага надається розвитку в лісових і степових районах скотарства, оскільки воно забезпечує населення цінними й висококалорійними харчовими продуктами. Зокрема, значна кількість поголів'я великої рогатої худоби сконцентровано в Аргентині, Бразилії, Індії, США, Китаї, Росії [5]. Водночас велике значення має молочне скотарство, котре масово розміщується в промислово розвинених країнах Північної Америки й Європи, Новій Зеландії та в країнах Балтії, Білорусії, Росії. Позитивне те, що в деяких країнах (Австралія, Нова Зеландія) застосовується цілорічний випас худоби на пасовищах або ж пасовищне утримання поєднується зі стійловим у зимовий час (Білорусь, Данія, Нідерланди, Росія, Фінляндія). 
Встановлено, що у високорозвинених європейських країнах державна політика спрямовується на розвиток тваринництва на інтенсивній основі, оскільки тут велика увага надається племінному відбору високопродуктивних порід, обладнанню та удобренню природних кормових угідь, механізації найбільш трудомістких робіт, через що досягнуто високих показників продуктивності молочної худоби. У розвинутих країнах удосконалення та оптимальне поєднання внутрішньоекономічних механізмів і механізмів державного впливу на розвиток молочної галузі забезпечують надійність і стабільність формування пропозицій молочної продукції.

Світовий рівень середньорічних надоїв молока від корів коливається в межах 2900-11775 кг молока (Ізраїль, США, Канада, Нідерланди, Швеція, Данія, Фінляндія) [6]. 3'ясовано, що найбільшими виробниками молока у світі $\in \in C$, Індія, США, Бразилія. Зокрема, в Данії, Нідерландах, США, Швеції надої молока від однієї корови перевищують 6 тис. кг, в Японії - 5 тис. кг, тоді як у Росії продуктивність корів становить 2,8 тис. кг, Аргентині - 2,6, Китаї - 1,6, Монголії 0,35 тис. кг. [1]. Україна знаходиться в другій десятці найбільших країн-виробників з обсягом 9,7 млн тон і має частку 1,3\% у світовому виробництві молока. В усіх категоріях господарств у 2019 р. в середньому за рік від однієї корови було отримано 4976 кг, що у 2 рази більше проти 2359 кг у 2000 р. [2, с. 20, 21].

Зазначимо, що значна кількість м'ясного поголів'я великої рогатої худоби вирощується в Латинській Америці (Аргентина, Бразилія, Мексика, Уругвай) і Східній Африці (Ефіопія), поголів'я овець і кіз у країнах Південно-західної та Південної Азії (Іран, Індія, Туреччина, Пакистан). На велику рогату худобу припадає майже 30 \% світового обсягу виробництва м'яса. Однак натепер його виробництво відбувається під впливом таких чинників, як коливання цін на енергоносії, зміни курсу американського долара, значне зростання цін на кормові ресурси й великий попит на продукцію з боку азійських держав. Головними виробниками й постачальниками світового ринку яловичини є Австралія, Бразилія, Нова Зеландія, Нідерланди, Канада, США, Аргентина [6]. Державна політика цих країн забезпечує підтримку виробників та їхне стимулювання постійного процесу відродження та покращення генетичних ознак стада.

Доречно зазначити, що світовий досвід ведення м'ясного скотарства показує, що успішний розвиток цієї галузі потребує мати спеціалізовані породи й типи м'ясної худоби, котрі добре пристосовуються до природно-кліматичних умов і місцеперебування, сучасні енергоощадні й мало витратні технології, повноцінну кормову базу.

Поповнює резерви м'ясної продукції вівчарство, особливістю котрого $є$ постійне зростання виробництва ягнятини й молодої баранини. В основному 40 \% світового поголів'я овець сконцентровано в Азії. В окремих країнах світу на вівчарство припадає майже 25\% обсягу продукції сільського господарства. Водночас у більшості країн виторг від реалізації м'яса складає майже $90 \%$, а від вовни лише біля 10\%. У більшості випадків у посушливих степах, напівпустелях і гірських районах країн розвивається скороспіле м'ясне (особливо популярною є ягнятина) й м'ясо-вовнове вівчарство.

Значна кількість поголів'я овець сконцентрована в Австралії, Аргентині, Новій Зеландії, Індії, Південній Європі, Туреччині, Казахстані, Росії, Монголії, Уругваї. Головними виробниками й експортерами баранини й вовни $€$ Австралія, Китай, Нова Зеландія, Аргентина, тоді як країни $€ C €$ важливими покупцями баранини на світовому ринку. Для інтенсивного розвитку вівчарства урядами зазначених країн фермерам надається державна підтримка й доступні дешеві кредити.

Збільшення обсягу м'ясних ресурсів, що використовуються для задоволення потреб населення в продуктах тваринного походження, значною мірою залежить від розвитку галузі свинарства, котра забезпечує 40 \% світового виробництва м'яса й шкіряної сировини. Свинарство розвивається в країнах із великою щільністю населення (Бразилії, Німеччині, США, Росії, Україні, Польщі). Урядами цих країн запроваджено систему субсидій, стимулів, страхування, а також вакцинації тварин для підвищення їхньої стійкості до різного роду захворювань.

З'ясовано, що заходами державної політики європейських країн високий рівень виробництва свинини забезпечується комплексним розв'язанням низки проблем: покращанням утримання та структури годівлі тварин, модернізацією виробничих процесів, якісною селекційно-племінною роботою, впровадженням нових і вдосконаленням традиційних технологій виробництва продукції, безпечним ветеринарно-санітарним обслуговуванням. Окрім цього, для збільшення обсягу виробництва конкурентоспроможної свинини важливе значення надається вдосконаленню наявних генофондів тварин, розведенню нових високопродуктивних порід, типів і ліній свиней із поліпшеними показниками якісного складу м'ясної продукції. 
Отже, в усіх європейських країнах тваринництво $€$ важливою галуззю не тільки за своїм значенням в аграрній економіці для стабільного функціонування кожної країни, але й за обсягами виробництва продукції, оскільки завдячуючи сприятливому природному середовищу й ефективному господарюванню практично всі країни повністю забезпечують власні потреби й експортують значні обсяги тваринницької продукції.

Нині основне завдання країн Європейського союзу полягає в соціально-ринковому підході до інтенсивного розвитку тваринництва. До важливих його особливостей належать підвищена роль держави в стимулюванні інноваційного розвитку галузі тваринництва через надання пільг, дотацій, субсидій виробникам тваринницької продукції з наданням одночасної уваги програмам розвитку сільських територій, досягнення оптимального співвідношення різних підгалузей, виробничої спеціалізації та концентрації поголів'я тварин.

Вважаємо, що пріоритетними напрямами забезпечення розвитку тваринництва в європейських країнах слід вважати підтримку структурної перебудови у тваринництві, котра повинна здійснюватися через інвестиції, активізацію чинників інтенсивного відтворення генетичного потенціалу шляхом поліпшення якості кормової бази, селекційно-племінної справи, проведення ветеринарних і санітарних заходів, впровадження сучасних інноваційних технологій для виробництва якісної тваринницької продукції.

Висновки. Дослідження показали, що важливою умовою інтенсивного розвитку тваринництва на підприємствах європейських країн $€$ дієвість державної підтримки, котра забезпечує прибутковість м'ясного скотарства й свинарства й сприяє зниженню рівня збитковості молочного скотарства. Надалі державна підтримка тваринництва повинна відповідати таким принципам: цілеспрямованість, оптимальність, системність, що сприятиме стійкості виробництва продукції тваринництва, підвищенню його ефективності й конкурентоспроможності.

Вважаємо, що серед основних заходів державної політики суттєву увагу в перспективі слід надавати цілеспрямованому процесу покращення племінних і продуктивних якісних характеристик тварин, використовуючи кращі зразки місцевого й світового генофондів; інтеграції тваринницьких суб'єктів господарювання з переробними підприємствами; стимулюванню державою тих господарств, котрі співпрацюють зі світовими лідерами в галузі тваринництва; впровадженню ефективних енергоощадних технологій утримання та годівлі тварин; вирощуванню високопродуктивного ремонтного молодняку; заготівлі, зберіганню та використанню високоякісних кормових ресурсів; модернізації на тваринницьких фермах машин та обладнання та виробничих процесів. Суттєвої уваги потребує проблема застосування критеріїв і процедур соціально-політичного спрямування державної політики й дієвих інструментів ії впровадження в різних сферах суспільного життя кожної європейської країни.

\section{ЛІТЕРАТУРА:}

1. Гуторов О.І. Світові тенденції розвитку молочного скотарства. Економіка АПК. 2011. № 6. C. 151-159.

2. Тваринництво України 2019 : статистичний збірник. Київ : Державна служба статистики України, 2020. 157c.

3. Agriculture The EU's common agricultural policy (CAP): for our food, for our countryside, for our environment. Luxembourg: Publications Office of the European Union, 2017. URL: https://ec. europa.eu/agriculture/ sites/agriculture/files/cap-overview/2016_en.pdf.

4. Heidenheimer A., Heclo H., Adams $\bar{C}$. Comparative Public Policy: The Politics of Social Choice in America, Europe and Japan. New York : St. Martin Press, 1990. $216 \mathrm{p}$.

5. ФАО: Мировой рынок мяса тревожит. Дайджест прессы 04.09 - 10.09: животноводство. URL: http://www.agro.ru/news/comments. .aspx?id=2929.

6. ФАО: Світовий ринок молока приростає. URL: http://www.agronews.ru/NewsP.php?NId=58713. 